\title{
CHEMICAL DEPENDENCE BY MARIJUANA USE: FROM PLEASURE TO ILLNESS. A SERIOUS PROBLEM IN PUBLIC HEALTH IN BRAZIL
}

\section{ORIGINAL ARTICLE}

DIAS, Amanda de Araújo¹, DIAS, Édina Lúcia de Araújo², OLIVEIRA, Ciane Martins de $^{3}$, DENDASCK, Carla Viana ${ }^{4}$, OLIVEIRA, Euzébio de ${ }^{5}$

DIAS, Amanda de Araújo Dias. Et al. Chemical dependence by marijuana use: from pleasure to illness. A serious problem in Public Health in Brazil. Revista Científica Multidisciplinar Núcleo do Conhecimento. Year 06, Ed. 03, Vol. 11, pp. 7886. March 2021. ISSN: 2448-0959, Access Link: https://www.nucleodoconhecimento.com.br/health/marijuana-use, 10.32749/nucleodoconhecimento.com.br/health/marijuana-use

\section{ABSTRACT}

Introduction: Marijuana use has increased globally, being the most widely used illicit drug in the world. It is estimated that between 167 and 315 million people between 15 and 64 years old used some illicit drug in the last decade. In Brazil, approximately 7.5 million university students, distributed in approximately 2,400 institutions make use of the herb. Method: A descriptive study was conducted based on a literature literature review. The research was carried out through the Scielo database and virtual health library (BVS). Results AND Discussion: Regarding the effects of marijuana, in some studies symptoms related to recreational use and abuse of this drug are reported. However, at the academic level, the effects of marijuana use can be divided into acute and chronic symptoms. Acute effects are classified as euphoria,

\footnotetext{
${ }^{1}$ Medical Academic at the University Center of the State of Pará - CESUPA.

2 Psychologist. Postgraduate in Mental Health at Escola Superior da Amazônia - ESAMAZ.

${ }^{3} \mathrm{PhD}$ in Medical Genetics. Professor and Researcher at the University Center of the State of Pará (CESUPA).

${ }^{4}$ Theologian, PhD in Clinical Psychoanalysis. He has been working for 15 years with Scientific Methodology (Research Method) in the Scientific Production Guidance of Master's and Doctoral students. Specialist in Market Research and Research focused on health.

${ }^{5} \mathrm{PhD}$ in Medicine/Tropical Diseases. Professor and Researcher at the Federal University of Pará - UFPA.
}

RC: 80473

Disponível em: https://www.nucleodoconhecimento.com.br/health/marijuana-use 
physical effects and psychic effects such as depression, hallucination, illusion, drowsiness and impairments of concentration and short-term memory. Conclusion: Some evidence is demonstrated that may explain why individuals choose to use marijuana. Most often the acute effects of euphoria, pleasure and relaxation are desired, in contrast, it is observed that the damages associated with this use end up overcoming the illusory benefits that the drug offers, thus leading to pleasure becoming an illness.

Keywords: Marijuana, consumption, pleasure, illness.

\section{INTRODUCTION}

The habit of using drugs has been present and established in societies since antiquity, and the first record of marijuana (cannabis) use dates back at least ten thousand years, in which there are records of cultivation and use by various civilizations around the world, being the oldest in Asia and the Middle East, later arriving in Africa, America and other regions (ROSA; ROSA, 2018).

It is estimated that between 167 and 315 million people between 15 and 64 years old used some illicit drug in the last decade, representing 3.6 to $6.9 \%$ of the world population. In this context, marijuana use has increased globally, being the most widely used illicit drug in the world. Marijuana is estimated to be consumed by 125 to 203 million people today, with the highest prevalence in Central and West Africa (GARCIA, 2014).

In Brazil, approximately 7.5 million university students, distributed in approximately 2,400 institutions use the herb, and the use of the substance is a frequent practice, much discussed by the lay media and analyzed by some scientific studies (GARCIA, 2014; FERNANDES et al., 2017).

RC: 80473

Disponível em: https://www.nucleodoconhecimento.com.br/health/marijuana-use 
Since the use of marijuana is increasingly frequent in our social environment, it is extremely important that studies be made in order to expand knowledge about its chemical, psychological and social effects due to the importance they present.

In addition, there has been discussion in recent years about the pros and cons related to the legalization of this drug, and for both professionals and the population to be able to give their opinion, it is necessary to first understand how marijuana modifies the body in the short and long term (COUTINHO; ARAÚJO; GONTIÈS, 2004).

In this context, this work is justified by being created in order to refine the existing knowledge about the use of marijuana and update the academic society about the process of pleasure and illness to which this drug is directly linked.

This review aims to address the main aspects of chemical dependence by marijuana use, as well as concepts about the pleasurable sensations of using this drug and how it is contributing to the desire to continue its use. It is also of interest to this article to discuss the physical and psychological consequences that marijuana originates in the body characterizing a process of illness by its prolonged use, contributing to better information about the reasons for not using this drug.

\section{MATERIAL AND METHOD}

The methodology used in the present study was a descriptive study based on a literature review. The bibliographic research was carried out through the Scielo database and the Virtual Health Library (BVS). To search the abstracts Portuguese in such bases, the following terms were used: marijuana, pleasure and illness. After this initial process, the titles were read, and then the abstracts, to select the publications that interested the research, based on the requirements established as inclusion and exclusion criteria. This research had as inclusion criteria articles published in the period from 2002 to 2020 , in the Portuguese language, which address the themes related to marijuana and its main physiological and pathological effects on the human

RC: 80473

Disponível em: https://www.nucleodoconhecimento.com.br/health/marijuana-use 
body, regarding body and mind. Exclusion criteria were papers published in a foreign language that did not meet the inclusion criteria. Finally, the selected articles were analyzed and originated the writing of the present work.

\section{LITERATURE REVIEW AND DISCUSSION}

\subsection{BASIC CONCEPTS RELATED TO MARIJUANA}

Marijuana is an herb whose scientific name is Cannabis. In Latin Cannabis means hemp, which it calls the plant family, and there are three types of species of this, being sativa, indica and ruderalis (FERRARI, 2016). The species, sativa and indica are the most used, both for smoking, as for various applications in cooking and medicine (CORTEZ, 2009).

For centuries the population has been using marijuana grass for medicinal purposes, for example, the Chinese pointed to the medicinal properties of marijuana as being anticonvulsant, soothing and analgesic. The potential of its medicinal properties in the treatment against some diseases is already scientifically proven, requiring further studies to analyze its effects in this sphere (RIBEIRO; MARQUES, 2008).

Cannabis sativa contains about 400 chemicals, at least 60 of them alkaloids, known as cannabinoids. The main psychoactive constituent of the plant is tetrahydrocannabiol (THC), one of the compounds of the herb, which also consists of other cannabinoids such as cannabidiol (CBD), cannabinol (CBN) and tetrahydrocanabivarin (THCV). These are divided into psychoactive (delta-8-THC, delta-9-THC and 11-hydroxy-delta-9-THC) and non-psychoactive (cannabidiol and cannabinol). Delta-9-THC is known to be the most potent of cannabinoids (SOLOWIJ; PESA, 2008; CORTEZ, 2009).

RC: 80473

Disponível em: https://www.nucleodoconhecimento.com.br/health/marijuana-use 


\subsection{THE EFFECT AND THE PLEASURE}

The main way to use marijuana grass is through smoking and the bioavailability of THC when smoked is about $20 \%$. Other forms of use can be performed through Haxixe which can also be smoked and has higher concentrations of THC, and Hashoil or Cannabis, which is the liquid and most potent form of the intravenous drug. When inhaled the smoke generated by the burned herb reaches the pulmonary alveolos, penetrates the blood circulation and reaches the brain in minutes (CORTEZ, 2009).

Oral absorption rates are higher (90 to $95 \%$ ) (30 to 45 minutes) in relation to pulmonary absorption (50\%). Pharmacological effects by pulmonary absorption can take between 5 to 10 minutes to start (SOLOWIJ; PESA, 2008; CORTEZ, 2009).

The peak effects caused by the drug occur in 30 minutes and ends after about two or three hours (CORTEZ, 2009).

Cannabinoids are deposited mainly in organs rich in adipose tissue, such as the brain and testicles, and therefore some users may exhibit signs and symptoms of intoxication for up to $12-24 \mathrm{~h}$ due to the slow release of these substances by adipocytes (SOLOWIJ; PESA, 2008).

THC half-life time can range from $20 \mathrm{~h}$ to 10 to 13 days and total elimination can take up to 30 days. Thus, if an individual uses marijuana repeatedly at intervals smaller than this, the concentration of THC in their blood will increase, causing more intense effects (SOLOWIJ; PESA, 2008; CORTEZ, 2009).

Marijuana cigarettes, widely found, although banned in some countries such as Brazil, are also known as "based", consisting of approximately $0.3-1 \mathrm{~g}$ of marijuana with a concentration of $1-15 \%$ delta-9-THC (2.5 to $150 \mathrm{mg} \mathrm{THC}$ ). In this context, it is observed that the production of euphoria effects occurs with a minimum concentration of $1 \%$ THC or 1 cigarette of 2 to $5 \mathrm{mg}$. And contrary to what many

RC: 80473

Disponível em: https://www.nucleodoconhecimento.com.br/health/marijuana-use 
think, the symptoms of intoxication already arise a few minutes after use (RIBEIRO; MARQUES, 2008; SOLOWIJ; PESA, 2008).

Regarding the effects of marijuana, in some studies symptoms related to recreational use and abuse of this drug are reported. However, at the academic level, the effects of marijuana use can be divided into acute and chronic symptoms. Acute effects are classified as euphoric (increased sexual desire, feeling of slowing time, increased self-confidence and grandeur, unmotivated laughter, hilarity, relaxation and increased perception of colors, sounds, textures and taste), physical effects (tachycardia, conjunctival hyperemia, dry mouth, hypothermia, dizziness, psychomotor retardation, motor incoordination, reduced visual acuity, increased hearing acuity, bronchodilation, increased appetite, cough and mydriasis) and psychic effects (depersonalization , disrealization, depression, hallucination, illusion, drowsiness, impairments of concentration and short-term memory, panic attacks and paranoia) (SOLOWIJ; PESA, 2008; CORTEZ, 2009).

\subsection{ABUSE AND ILLNESS}

Some authors induce that the consumption of psychoactive substances has been going through times and cultures, being used in religious rituals, as a therapeutic method and in the search for pleasure, emphasizing hedonism as a reference in this process (COUTINHO; ARAÚJO; GONTIÈS, 2004).

In a short-term period, one can observe the harmful effects of marijuana use, such as motor deficits, when performing tasks such as driving, for example; and cognitive problems, concentration and memory and consequently learning difficulties. On the other hand, long-term use can be marked by chronic cough, altered immunity, reduced testosterone levels and the development of mental illnesses such as schizophrenia, depression, panic attacks, anxiety, irritability, demotivation by life, hallucinations and depersonalization. The higher the dose consumed, the more intense the effects and rates of illnesses will be. Dependence on marijuana use occurs to the extent of its consumption. Adverse effects include amnesia, lack of

RC: 80473

Disponível em: https://www.nucleodoconhecimento.com.br/health/marijuana-use 
attention, motor problems, generation of dependence and withdrawal crises (RIBEIRO; MARQUES, 2008; SOLOWIJ; PESA, 2008).

Some studies show cognitive dysfunction in cannabis users during intoxication, several hours after the act of smoking it, after a few days and lasting damage for more than 1 month after discontinuation of use. The chronicity of cognitive alterations depends on the organism, dose and periodicity that the individual makes use of the herb, but it is important to emphasize that since the first use of the drug and after the onset of THC action, these psychic losses are already manifested (RIBEIRO; MARQUES, 2008).

The relationships between cognitive performance and frequency of cannabis use may indicate a residual effect of acute or chronic intoxication that would probably dissipate with cessation of use. Some studies report that the recovery of cognitive function is not fully elucidated, but in some sources it is found that recovery may occur after 1 month of abstinence or does not occur in 1 month or recovery may be only partial (RIBEIRO; MARQUES, 2008; SOLOWIJ; PESA, 2008).

The use of marijuana can also result in structural changes in the brain, such as the reduction in the volumes of the hippocampus and amygdala, and it cannot yet be affirmed that these effects are reversible. But through this process one can understand the real reason that cognitive impairment is more frequently detected in memory, executive function, attention and inhibitary control (SOLOWIJ; PESA, 2008).

In this context, it is interesting to note that the subject who uses marijuana may or may not have an apparent reason to perform such use, and among the main stimulating factors for the consumption of the drug can be mentioned: escape from the problems, curiosity, search for pleasures and social influence.

RC: 80473

Disponível em: https://www.nucleodoconhecimento.com.br/health/marijuana-use 


\section{CONCLUSION}

It can be observed that the use of marijuana implies a series of both acute and chronic effects, as well as residual, related to the mechanism of action of THC. In addition, users of this drug often have problems that affect their family, professional and social life.

In this context, it is interesting to observe that the subject who uses marijuana may or may not have an apparent reason to perform the use, but what arouses the desire to promote studies on the bridge between pleasure and illness is what is behind the search for the substance, a fact that is beyond the user's eyes and the conscious.

In the present study, some evidence is demonstrated that may explain the reasons why individuals choose to use marijuana. Most often the acute effects of euphoria, pleasure and relaxation are desired, in contrast, it is observed that the damages associated with this use end up overcoming the illusory benefits that the drug offers, thus leading to pleasure becoming an illness.

\section{REFERENCES}

CORTEZ, P. Possíveis efeitos cognitivos e psicomotores em usuários crônicos de Cannabis. 2009.

COUTINHO, M. P. L.; ARAÚJO, L. F.; GONTIÈS, B. Uso da maconha e suas representações sociais: estudo comparativo entre universitários. Psicologia em Estudo, Maringá, v. 9, n. 3, p. 469-477, set./dez. 2004.

FERNANDES, T. F.; MONTEIRO, B. M. M.; SILVA, J. B. M.; OLIVEIRA, K. M.; VIANA, N. A. O.; GAMA, C. A. P.; GUIMARÃES, D. A. Uso de substâncias psicoativas entre universitários brasileiros: perfil epidemiológico, contextos de uso e limitações metodológicas dos estudos. Cad. Saúde Colet., 2017, Rio de Janeiro, 25 (4): 498-507.

RC: 80473

Disponível em: https://www.nucleodoconhecimento.com.br/health/marijuana-use 
FERRARI, C. R. Cannabis. Universidade de São Paulo. Instituto de Física de São Carlos - Psicologia da Educação - SLC 0631. Licenciatura em Ciências Exatas. 2016. 15p.

GARCIA, F. D. Manual de abordagem de dependências químicas. ED. Utopika, 2014, 386p.

RIBEIRO, M; MARQUES, A.C. P. R. Projeto diretrizes: Abuso e dependência Maconha. 2008.

ROSA, P.; ROSA, M. G. Políticas sobre cannabis: um estudo comparativo sobre os modelos da Espanha. Geographia Opportuno Tempore Universidade Estadual de Londrina EISSN: 2358-1972, Volume 4, Número 1, 2018 Uruguai e Colorado/EUA, 2018.

SOLOWIJ, N,; PESA, N. Anormalidades cognitivas no uso da cannabis. 2010.

Submitted: March, 2021.

Approved: March, 2021.

RC: 80473

Disponível em: https://www.nucleodoconhecimento.com.br/health/marijuana-use 